\title{
PENGARUH MODEL PEMBELAJARAN STUDENT FACILITATOR AND EXPLAINING UNTUK MENINGKATKAN KEMAMPUAN EKSPLORASI MAHASISWA
}

\author{
Chairunnisa Amelia ${ }^{1)}$ Eko Febri Syahputra ${ }^{2)}$ \\ ${ }^{1)}$ Universitas Muhammadiyah Sumatera Utara : Jl. Kapten Mukhtar Basri No. 3 Medan \\ Email : chairunnisaamelia@umsu.ac.id
}

\begin{abstract}
Tujuan Penelitian untuk mengetahui pengaruh model pembelajaran student facilitator and explaining dan untuk mengetahui peningkatan keterampilan peserta didik dalam kemampuan eksplorasi mahasiswa materi penegakan hukum di Indonesia Program Studi Pendidikan Guru Sekolah Dasar FKIP UMSU tahun ajaran 2018-2019. Populasi mahasiswa semester I Program Studi Pendidikan Guru Sekolah Dasar FKIP UMSU tahun pembelajaran 2018-2019 berjumlah 82 mahasiswa yang terdiri atas 2 kelas, yaitu kelas A pagi, B pagi, sampel penelitian Random sampling. Penelitian ini menggunakan metode eksperimen dengan desain two-group post-test and only design. Uji normalitas kelas eksperimen menunjukkan sig. 0.031 dan kelas control menunjukkan sig. 0,061. uji homogenitas, untuk kelas eksperimen sebesar 0,797 dan kelas control sebesar 0,524. uji pengaruh/linearitas untuk kelas eksperimen dan kelas control berskor 0,00 yang berarti ada pengaruh antara model eksperimen dan model control terhadap eksplorasi mahasiswa, besarnya pengaruh model eksperimen terhadap eksplorasi sebesar 63,6\%. Sedangkan model control sebesar 27,4\%.
\end{abstract}

Kata kunci : Model pembelajaran student facilitator, explaining dan model pembelajaran konvensional, Kemampuan eksplorasi

\begin{abstract}
The aims of the study were to determine the effect of the student facilitator and explaining learning model and to determine the improvement of students' skills in the ability to explore law enforcement material in Indonesia at the Primary School Teacher Education Study Program FKIP UMSU 2018-2019 academic year. The first semester student population of Primary School Teacher Education Study Program FKIP UMSU 2018-2019 amounted to 82 students consisting of 2 classes, namely class A morning, B morning, the sample of study was Random sampling. This study used an experimental method with two-group post-test and only design. The normality test of the experimental class showed sig. 0.031 and the control class showed sig. 0.061 . Homogeneity test, for the experimental class was 0.797 and the control class was 0.524 . Test the effect / linearity for the experimental class and the control group 0.00, which meant that there was an influence between the experimental model and the control model on student exploration, the influence of an experimental model to the exploration was $63.6 \%$. While the control model was $27.4 \%$.
\end{abstract}

Keywords: Student facilitator learning model, explaining and conventional learning models, exploration capabilities. 


\section{PENDAHULUAN}

Pendidikan memegang peranan penting dalam menentukan tingkat kemampuan seseorang dalam menghadapi kehidupan. Pendidikan yang memadai, membuat kita hidup sesuai dengan kondisi yang diharapkan. Pendidikan bentuk perwujudan kebudayaan manusia yang dinamis dan sarat perkembangan. Oleh karena itu perkembangan pendidikan harus sejalan dengan perubahan budaya kehidupan. Perubahan diartikan perbaikan pendidikan pada semua aspek yang perlu terus gali dilakukan sebagai antisipasi kepentingan pada masa akan datang. Hal ini erat hubungannya dengan berbagai bidang ilmu, tidak terkecuali pada bidang pendidikan terutama Pendidikan Guru Sekolah Dasar.

Dewasa ini, Proses pembelajaran yang sering dipakai yaitu memusatkan pada dosen (pendidik) daripada memusatkan pada mahasiswa atau peserta didik, halini berdampak pada suatu alasan sebuah materi pembelajaran menjadi membosankan dan dianggap tidak menarik. Hal tersebut juga mengakibatkan peran mahasiswa sangat kecil, hal sebaliknya jika mahasiswa dilibatkan secara lebih aktif didalam proses pembelajaran maka prestasi dalam diri mereka pada materi pembelajaran dapat berhasil bahkan menggembirakan dan berkemajuan sesuai dengan impian pendidikan itu sendiri.

Peneliti melakukan observasi terhadap proses belajar mengajar pada mahasiswa, hal ini menunjukkan terdapat beberapa masalah yang dihadapi dalam proses pembelajaran IPS, diantaranya metode pembelajaran yang digunakan metode ceramah, observasi, demonstrasi dan diskusi dan banyak mahasiswa yang tidak memperhatikan disaat dosen menjelaskan terlebih lagi dengan pembelajaran Ilmu Pengetahuan Sosial (IPS), maka tentunya mahasiswa diharapkan mampu menguasai keterampilan-keterampilan dalam pembelajaran IPS, diantaranya keterampilan eksplorasi atau mengkomunikasikan.

Keterampilan eksplorasi atau mengkomunikasikan merupakan keterampilan dalam menyampaikan apa yang ada didalam pikiran dan perasaan kepada orang lain, baik secara lisan maupun secara tertulis. berdasarkan kondisi tersebut, diperlukan adanya perubahan agar proses pembelajaran IPS lebih berarti bagi mahasiswa. Dosen harus dapat menggunakan dan menentukan model dan metode pembelajaran yang sesuai, sehingga minat mahasiswa bertambah dan tertarik untuk mengikuti proses pembelajaran serta dapat meningkatkan keterampilanketerampilan pada pembelajaran IPS.

Menjawab permasalah tersebut diperlukan model pembelajaran yang diharapkan dapat memecahkan masalah tersebut, sehingga peneliti melakukan penelitian berjudul "Pengaruh Model Pembelajaran Student Facilitator And Explaining Untuk Meningkatkan Kemampuan Eksplorasi Mahasiswa". Pada model pembelajaran student facilitator and explaining ini lebih difokuskan kepada mahasiswa daripada dosen.

Tujuan Penelitian ini untuk mengetahui pengaruh model pembelajaran student facilitator and explaining dalam kemampuan eksplorasi mahasiswa materi penegakan hukum di Indonesia Program Studi Pendidikan Guru Sekolah Dasar FKIP UMSU tahun ajaran 2018-2019.

\section{Pengertian Model Pembelajaran Student Facilitator and Explaining}

\subsection{Model Pembelajaran Student Facilitator and Explaining}

Istarani (2011: 1) berpendapat bahwa model pembelajaran merupakan seluruh rangkaian penyajian materi ajar yang meliputi segala aspek sebelum, sedang, sesudah pembelajaran yang dilakukan pendidik serta fasilitas yang terkait yang dipakai secara langsung atau tidak langsung dalam proses belajar 
mengajar. Menurut Artz dan Newman dalam Miftahul Huda (2013), mendefinisikan pembelajaran Cooperative sebagai kelompok kecil siswa yang bekerja sama dalam suatu tim untuk mengatasi suatu masalah, menyelsaikan sebuah tugas, atau mencapai satu tujuan bersama.

Abram Rinekso (2012:22) menyatakan bahwa Model Student Facilitator And Explaining memiiki arti metode yang membuat siswa dapat membuat peta konsep atau bagan untuk meningkatkan kreatifitas siswa dan prestasi belajar siswa. Dimana dalam metode Student Facilitator And Explaining siswa dapat menjelaskan dengan bagan atau peta konsep.

Model Student Facilitator and Explaining merupakan rangkaian penyajian materi ajar yang dimulai dengan penjelasan secara terbuka, memberi kesempatan siswa/peserta didik untuk menerangkan kembali kepada teman-temannya dan diakhiri dengan penyampaian semua materi kepada siswa. Model pembelajaran Student Facilitator and Explaining adalah model pembelajaran yang digunakan oleh pendidik dengan maksud memberikan kesempatan kepada peserta didik untuk berperan menjadi narasumber terhadap temannya di kelas. Model pembelajaran Student Facilitator and Explaining merupakan model pembelajaran dimana siswa/peserta didik dapat belajar berpendapat / mempresentasikan ide pada rekan peserta didik lainnya. Model pembelajaran ini efektif untuk melatih siswa berbicara untuk menyampaikan pendapatnya sendiri.

Model pembelajaran Student Facilitator And Explaining diyakini dapat meningkatkan antusias, motivasi, keaktifan, dan rasa senang pada pembelajar (mahasiswa), model pembelajaran ini cocok untuk mata kuliah ilmu pengetahuan sosial. Pada model ini mahasiswa melakukan langkah yaitu mendemonstrasikan materi di depan mahasiswa lain kemudian memberikan kesempatan kepadanya untuk menjelaskan kepada mahasiswa lain.

\subsection{Langkah-langkah Model Pembelajaran Student Facilitator and Explaining}

Setiap pembelajaran memiliki langkah-langkah dalam pelaksanaanya. Model pembelajaran ini, peserta didik mempresentasikan ide/pendapat pada peserta didik lainnya. Pada model pembelajaran ini peserta didik dapat belajar menyampaikan ide dan gagasan. Berikut adalah langkah-langkahnya :

1. Dosen memberitahukan kompetensi yang ingin dicapai,

2. Dosen mempresentasikan/ menyajikan materi,

3. Dosen membuka kesempatan mahasiswa untuk menjelaskan kepada mahasiswa lainnya baik dalam bentuk bagan/peta konsep maupun lainnya,

4. Dosen membuat kesimpulan atas ide/pendapat dari mahasiwa,

5. Dosen menyampaikan semua materi yang disajikan saat ini,

6. Evaluasi,

7. Refleksi,

8. Penutup.

\subsection{Kelebihan dan Kekurangan Model Pembelajaran Student Facilitator and Explaining}

Dalam penggunaan suatu model pembelajaran tentunya terdapat suatu kelebihan yang dimilikinya, tidak terlepas kelemahan didalamnya.

Kelebihan dari metode pembelajaran Student Facilitator and Explaining yitu :

a. Membuat materi yang disampaikan lebih jelas dan konkret,

b. Meningkatkan daya serap mahasiswa karena pembelajaran dilakukan dengan demonstrasi,

c. Melatih mahasiswa untuk menjadi fasilitator, mahasiswa diberi kesempatan untuk mengulangi penjelasan dosen yang telah didengar, 
d. Memberikan motivasi kepada mahasiswa untuk menjadi yang terbaik dalam menjelaskan materi ajar,

e. Mengetahui kemampuan mahasiswa dalam menyampaikan ide atau gagasan.

Akan tetapi, metode Student Facilitator and Explaining ini juga memiliki beberapa kelemahan, antara lain:

a. Mahasiswa yang bersifat pemalu merasa sulit untuk mempresentasikan dan atau mendemonstrasikan apa yang diperintahkan oleh dosen,

b. Keterbatasan waktu pembelajaran mengakibatkan tidak semua mahasiswa memiliki kesempatan yang sama untuk menjelaskan kembali kepada teman-temannya,

c. Adanya pendapat yang sama sehingga hanya sebagian mahasiswa yang terampil,

d. Tidak mudah bagi mahasiswa untuk membuat peta konsep atau menerangkan materi ajar secara ringkas.

\subsection{Manfaat Penerapan Model Pembelajaran Student Facilitator and Explaining}

Manfaat dilaksanakannnya Model Student Facilitator and Explaining yaitu

a. Mahasiswa dapat memiliki waktu yang lebih banyak dalam mengerjakan tugas dan untuk mendengarkan satu sama lain. Dampaknya, pemahaman materi pembelajaran lebih dipahami, kondisi dapat dilihat dengan banyaknya siswa/peserta didik yang akan mengangkat tangan untuk menjawab pertanyaan dengan pasangannya.

b. Dosen memiliki waktu yang lebih banyak untuk berfikir dan berkonsentrasi mendengarkan jawaban mahasiswa, dan dapat dengan seksama mengamati reaksi mahasiswa, dan mengajukan pertanyaan yang lebih detil.

\section{Model Konvensional}

\subsection{Pengertian Model Konvensional}

Menurut Russeffendi (2005:17), "Model konvensional, pendidik dianggap sebagai gudang ilmu, bertindak otoriter, mendominasi kelas. Pendidik mengajarkan ilmu, langsung membuktikan dalil, membuktikan contoh soal". Sedangkan mahasiswa harus duduk rapi mendengarkan, meniru pola yang diberikan dosen, mencontoh cara dosen menyelesaikan soal. Mahasiswa yang kurang memahaminya terpaksa mendapat nilai kurang/jelek dan karena itu mungkin sebagian dari mereka tidak naik kelas.

Pada pembelajaran konvensional ditandai dengan ceramah yang diiringi dengan penjelasan, serta pembagian tugas dan latihan. Sejak dahulu dosen/guru dalam usaha menularkan pengetahuannya pada mahasiswa/siswa ialah secara lisan atau ceramah. Pembelajaran konvensional yang dimaksud adalah pembelajar yang biasa dilakukan oleh para dosen/guru. Pembelajaran konvensional (tradisional) pada umumnya memiliki kekhasan tertentu, misalnya lebih mengutamakan hafalan daripada pengertian, menekankan kepada keterampilan berhitung, mengutamakan hasil daripada proses, dan pengajaran berpusat pada pengajar.

Model konvensional dianggap sebagai penyebab utama dari rendahnya minat belajar mahasiswa terhadap pelajaran memang patut dibenarkan, tetapi juga anggapan itu tidak sepenuhnya tepat karena setiap model pembelajaran baik model pembelajaran klasik termasuk model konvensional maupun model pembelajaran modern sama-sama mempunyai kelebihan dan kekurangan masing-masing yang melengkapi satu sama lain. 


\section{Kajian Materi}

\subsection{Penegakan Hukum Di Indonesia}

Saat ini tidak mudah untuk memaparkan kondisi hukum di Indonesia tanpa adanya keprihatinan yang mendalam mendengar ratapan masyarakat yang terluka oleh hukum. Dunia hukum di Indonesia tengah mendapat sorotan yang amat tajam dari seluruh lapisan masyarakat, baik dari dalam negeri maupun luar negri.Dari sekian banyak bidang hukum, dapat dikatakan bahwa hukum pidana menempati peringkat pertama yang bukan saja mendapat sorotan tetapi juga celaan yang luar biasa dibandingkan dengan bidang hukum lainnya. Bidang hukum pidana merupakan bidang hukum yang paling mudah untuk dijadikan indikator apakah reformasi hukum yang dijalankan di Indonesia sudah berjalan dengan baik atau belum.

\subsection{Kelebihan dan Kelemahan Penegakan Hukum Indonesia}

Dalam pelaksanaannya sistem hukum yang ada di Indonesia tentunya ada kelemahan dan juga kelebihannya. Menurut Mohamad Sahril Pontoh (2014), berikut adalah mengenai kelebihan dan kelemahan pelaksanaan sistem hukum Indonesia.

\section{Kelebihan}

Kelebihan sistem hukum Indonesia diantaranya adalah bahwa susunan perundang-undangan di Indonesia di susun secara baik dan sistematis, dari mulai peraturan yang paling atas hingga yang paling rendah, dan antara peraturan-peraturan tersebut tidak saling tumpang tindih karena di atur oleh berbagai macam adagium. Indonesia memiliki Pancasila sebagai dasar negara dan UUD'45 sebagai sumber hukum yang paling utama dan teratas. UUD'45 terkenal paling sempurna di dunia walau hanya dengan beberapa Pasal saja di dalamnya, dan di dalam pembukaannya, UUD'45 mengatur keseluruhan dari kehidupan berbangsa dan bernegara yang merdeka dan berserikat.

2. Kelemahan

Berikut beberapa kelemahan sistem hukum di Indonesia :

a.Campur Tangan Politik. Kasuskasus hukum di Indonesia banyak yang terhambat karena adanya campur tangan politik didalamnya

b.Peraturan perundangan yang lebih berpihak kepada kepentingan penguasa

dibandingkan kepentingan rakyat.

c.Rendahnya integritas moral, kredibilitas, profesionalitas dan kesadaran hukum aparat penegak hukum dalam menegakan hukum.

d.Kedewasaan Berpolitik. Berbagai sikap yang diperlihatkan oleh partai politik saat kadernya terkena kasus poltik sesungguhnya memperlihatkan ketidakdewasaan para elit politik di Negara hukum ini

\subsection{Permasalahan Penegakan Hukum Di Indonesia}

Permasalahan disebabkan berbagai hal mulai dari sistem peradilannya, perangkat hukumnya, tidak konsistennya para aparat penegak hukum terhadap hukum itu sendiri serta intervensi kekuasaan maupun perlindungan hukum terhadap masyarakatnya yaitu diantaranya:

1. Adanya Transaksional dalam Penegakan Hukum

2. Degradasi Moral Penegak Hukum yang Buruk

3. Ada Intervensi dari Penguasa

4. Masyarakat Belum Sadar Hukum

5. Masyarakat Sudah Tahu Hukum tapi Tetap Melanggar

6. Ketimpangan antarpasal

\subsection{Pemecahan Problematika Penegakan Hukum di Indonesia}


Beberapa pemecahan dari berbagai problematika penegakan hukum di Indonesia :

1. Bagaimana sikap serta tindakan para sarjana hukum untuk lebih memperluas cakrawalanya dalam memahami atau menganalisis masalah-masalah yang terjadi sekarang ini.

2. Bagaimana tindakan para aparat penegak hukum mulai dari polisi, hakim, jaksa, serta pengacara dalam menangani setiap kasus hukum dengan dilandasi nilai-nilai kejujuran, keadilan, serta melakukan proses-proses hukum sesuai dengan aturan yang ada di dalam undangundang negara kita.

3. Program jangka panjang yang perlu dilakukan yaitu penerapan pendidikan karakter dalam setiap tingkatan pendidikan. Untuk mengetahui tingkat keefektifan

4. Adanya penghargaan bagi jaksa dan hakim berprestasi yang memberikan terobosan-terobosan dalam penegakan hukum di Indonesia.

\subsection{Dampak Penegakan Hukum Di Indonesia}

Akibat-akibat yang ditimbulkan dari masalah penyelewengan hukum diantaranya, yaitu:

1. Ketidakpercayaan masyarakat pada hukum

2. Penyelesaian konflik dengan kekerasan

3. Pemanfaatan Inkonsistensi Penegakan Hukum untuk Kepentingan Pribadi

\subsection{Penerapan Model Pembelajaran Student Facilitator and Explaining pada Pembelajaran Ilmu Pengetahuan Sosial (IPS)}

Model pembelajaran Student Facilitator and Explaining merupakan model pembelajaran dimana peserta didik belajar mempresentasikan ide/pendapat pada rekan peserta didik lainnya. Model pembelajaran ini efektif untuk melatih siswa berbicara untuk menyampaikan ide/gagasan atau pendapatnya sendiri.

Dari pengertian tersebut dapat disimpulkan bahwa model pembelajaran Student Facilitator and Explaining dapat diterapkan pada mata pelajaran IPS yang ada di Fakultas Keguruan dan Ilmu Pendidikan (FKIP UMSU ). Model ini sesuai apabila diterapkan pada pembelajaran IPS karena pada model pembelajaran ini peserta didik dapat melatih keterampilan mengeksplorasi materi dan menyampaikan pendapat atau idenya. Pada dasarnya, hakikat IPS adalah ilmu pengetahuan yang mempelajari, menelaah, menganalisis dengan meninjau dari berbagai aspek kehidupan

Dengan demikian, semakin jelas bahwa proses belajar mengajar IPS lebih ditekankan pada pendekatan keterampilan proses, hingga peserta didik dapat menemukan fakta-fakta, membangun konsep-konsep, teori-teori dan sikap sosial. Dalam pendekatan proses, terdapat beberapa keterampilan yang harus dikuasai oleh peserta didik, salah satunya yaitu keterampilan eksplorasi. Keterampilan eksplorasi adalah mengatakan apa yang diketahui dengan ucapan kata-kata, gambar, demonstrasi atau grafik.

Jadi, dengan menerapkan metode pembelajaran Student Facilitator and Explaining pada mata pelajaran IPS diharapkan peserta didik dapat menyampaikan ide atau pendapatnya dan dapat memaksimalkan keterampilan eksplorasi.

\section{Hipotesis}

Hipotesis penelitian merupakan jawaban sementara terhadap permasalahan penelitian, sampai terbukti melalui data yang terkumpul.Oleh karena itu, dapat dirumuskan hipotesis penelitian ini adalah "Ada pengaruh signifikan model pembelajaran student facilitator and explaining dalam kemampuan eksplorasi mahasiswa materi penegakan hukum di Indonesia Program Studi Pendidikan Guru Sekolah 
Dasar FKIP UMSU tahun ajaran 20182019”.

\section{METODE}

Penelitian ini menggunakan instrumen data dalam bentuk tes esai. metode eksperimen dengan desain two-group post-test and only design. Untuk lebih jelasnya desain penelitian yang digunakan dapat dilihat pada tabel 1 berikut ini :

Tabel 1

Desain Penelitian Posttes-Only Control Design

\begin{tabular}{|c|c|c|c|}
\hline KELOMPOK & KELAS & $\begin{array}{c}\text { PERLA- } \\
\text { KUAN }\end{array}$ & $\begin{array}{c}\text { POST } \\
\text {-TEST }\end{array}$ \\
\hline (Eksperimen) & A pagi & $\mathrm{X}_{1}$ & $\mathrm{~T}_{1}$ \\
\hline (Kontrol) & B pagi & $\mathrm{X}_{2}$ & $\mathrm{~T}_{2}$ \\
\hline
\end{tabular}

\section{Lokasi Penelitian}

Penelitian ini dilaksanakan pada mahasiswa semester 1 yang mengambil materi Penegakan Hukum di Indonesia pada Program Studi Pendidikan Guru Sekolah Dasar FKIP UMSU tahun ajaran 2018-2019 yang berada di Jalan Muchtar Basri nomor 3 Medan.

\section{Populasi dan Sampel}

\section{Populasi}

Populasi dalam penelitian ini adalah mahasiswa semester I Program Studi Pendidikan Guru Sekolah Dasar FKIP UMSU tahun pembelajaran 20182019 yang berjumlah 82 mahasiswa yang terdiri atas 2 kelas, yaitu kelas A pagi, B pagi. Random sampling menjadi pilihan pada penelitian ini dalam menentukan sampel. Setiap kelas memiliki potensi yang sama untuk dipilih menjadi sampel. Setiap kelas diberi nomor undian tersebut, untuk dijadikan sebagai sampel.

Langkah-langkah pemilihan sampel sebagai berikut : a. Menuliskan nomor urut kelas pada kertas kecil dari kelas A pagi, B pagi.

b. Membuat gulungan kertas sebanyak jumlah kelas yang telah diberi nomor urut.

c. Gulungan kertas tersebut dimasukkan kedalam wadah, lalu diguncang-guncang dan dikeluarkan sebanyak dua gulungan.

d. Gulungan kertas pertama kali keluar ditetapkan sebagai kelas eksperimen dan gulungan kertas kedua yang keluar ditetapkan sebagai kelas kontrol.

Berdasarkan pengambilan sampel, maka ditentukan kelas B pagi sebagai kelas eksperimen berjumlah 41 orang dan kelas A pagi sebagai kelas kontrol berjumlah 41 orang.

\section{Variabel Penelitian}

Dalam penelitian ini terdapat variabel yaitu :

1. Variabel bebas $\left(\mathrm{X}_{1}\right)$ : model pembelajaran student facilitator and explaining.

2. Variabel terikat $(\mathrm{Y})$ : Kemampuan eksplorasi pada mata kuliah IPS materi penegakan hukum di Indonesia

\section{Teknik Analisis Data}

\section{Uji Prasayarat}

\section{Uji Normalitas}

Mengetahui data berdistribusi normal maka perlu dilakukan uji normalitas data. Pengujian dilakukan untuk memeriksa apakah sampel yang diambil mempunyai kesesuain dengan populasi. Uji kenormalan yang digunakan adalah uji Kolmogorov-Smirnov (Sya'ban, 2005).

Penelitian ini dengan menggunakan uji Kolmogorov Smirnov. Pengujian dilakukan pada masing-masing variabel dengan 
asumsi datanya berdistribusi normal. Hipotesis yang akan dilakukan pengujian adalah sebagai berikut:

H0 : Data berdistribusi Normal

Ha : Data tidak berdistribusi Normal Statistik uji Kolmogrov Smirnov (K$\mathrm{S})$ dihitung menggunakan program SPSS for Windows. Kriteria ujinya ialah terima $\mathrm{H} 0$, jika nilai K-S lebih kecil dari K-S tabel, atau jika p-value lebih besar dari $a$. Data dinyatakan berdistribusi normal apabila $\mathrm{D}_{\text {hitung }}<$ $\mathrm{D}_{\text {tabel }}$ pada taraf kesalahan tertentu.

\section{Uji Homogenitas}

Pengujian homogenitas varians dilakukan untuk memastikan bahwa kelompok-kelompok yang dibandingkan merupakan kelompokkelompok yang mempunyai varians homogen. Perbandingan harus meliputi kelompok-kelompok yang homogeny sehingga dapat diklaim bahwa perubahan yang terjadi yang menyebabkan perbedaan kelompok setelah perlakuan hanya disebabkan oleh pemberian perlakuan (Sugiyono,2013).

Pengujian homogenitas pada penelitian ini dihitung dengan bantuan paket program SPSS for Windows. Kelompok-kelompok yang dibandingkan dikatakan mempunyai varians yang homogen apabila $F_{\text {hitung }}$ $<\mathrm{F}_{\text {tabel }}$ kriteria pengujiannya adalah:

1) H0 diterima apabila harga Fhitung < Ftabel, berarti data berdistribusi normal.

2) H0 ditolak apabila harga $F_{\text {hitung }}>$ $\mathrm{F}_{\text {tabel }}=0,05(5 \%)$ dari derajat kebebasan, berarti data tidak berdistribusi normal.

\section{Uji Hipotesis}

Untuk menguji hipotesis ini dilakukan dengan cara membandingkan nilai $t_{\text {hitung }}$ dengan $t_{\text {tabel }}$ dengan tingkat kepercayaan $\alpha=0,05$ dengan kriteria sebagai berikut :

Jika $t_{\text {hitung }}>t_{\text {tabel, }}$ maka Ha diterima

Jika $t_{\text {hitung }}<t_{\text {tabel, }}$ maka Ho diterima Apabila $t_{\text {hitung }}>t_{\text {tabel, }}$ maka Ha diterima dan Ho ditolak dengan pengertian ada pengaruh model pembelajaran student facilitator and explaining terhadap kemampuan eksplorasi mahasiswa pada materi penegakan hukum di Indonesia. Apabila $t_{\text {hitung }}<\mathrm{t}_{\text {tabel }}$ maka Ha ditolak dan Ho diterima dengan pengertian tidak ada pengaruh model pembelajaran student facilitator and explaining terhadap kemampuan eksplorasi mahasiswa pada materi penegakan hukum di Indonesia.

\section{HASIL DAN PEMBAHASAN}

Pada hasil perhitungan spss, nilai normalitas kelas eksperimen pada tabel. 2 menunjukkan sig. 0.031. ini berarti < 0,05 sehingga dapat disimpulkan data tidak normal, sedangkan Pada tabel. 3, untuk kelas control menunjukkan sig. 0,061 . Ini menunjukkan bahwa sig. > 0,05 . Hal ini menunjukkan bahwa data pada kelas kontrol normal.

Tabel 2

Uji Normalitas Kelas Eksperimen

\begin{tabular}{|l|r|r|}
\hline & & $\begin{array}{r}\text { Unstandardized } \\
\text { Predicted Value }\end{array}$ \\
\hline N & & 41 \\
Normal Parameters & \\
& Mean & 90.3170732 \\
& Std. Deviation & 4.58513302 \\
Most Extreme $\quad$ Absolute & .226 \\
Differences & Positive & .226 \\
\multicolumn{2}{|c|}{$\quad$ Negative } & -.135 \\
Kolmogorov-Smirnov Z & 1.444 \\
Asymp. Sig. (2-tailed) & .031 \\
\hline
\end{tabular}

Tabel 3

Uii Normalitas Kelas Control

\begin{tabular}{|c|c|c|}
\hline & & $\begin{array}{l}\text { Unstandardized } \\
\text { Predicted Value }\end{array}$ \\
\hline \multicolumn{2}{|l|}{$\mathrm{N}$} & 41 \\
\hline \multirow[t]{2}{*}{ Normal Parameters ${ }^{\mathrm{a}}$} & Mean & 66.1951220 \\
\hline & Std. Deviation & 5.65704853 \\
\hline \multirow{3}{*}{$\begin{array}{l}\text { Most Extreme } \\
\text { Differences }\end{array}$} & Absolute & .206 \\
\hline & Positive & .206 \\
\hline & Negative & -.089 \\
\hline \multirow{2}{*}{\multicolumn{2}{|c|}{$\begin{array}{l}\text { Kolmogorov-Smirnov Z } \\
\text { Asymp. Sig. (2-tailed) }\end{array}$}} & 1.320 \\
\hline & & 061 \\
\hline \multicolumn{2}{|c|}{ a. Test distribution is Normal. } & \\
\hline
\end{tabular}


Berdasarkan hasil uji homogenitas, pada tabel. 4 untuk kelas eksperimen didapat hasil sig sebesar 0,797. Hal Ini mengartikan sig $>0,05$, Sehingga antara model dan eksplorasi memiliki hubungan yang positif dan linier. Sedangkan pada pada tabel. 5 untuk kelas control didapat hasil sig sebesar 0,524 . Hal Ini mengartikan sig > 0,05 yang berarti kelas control dan eksplorasi juga memiliki hubungan yang linier. Sehingga dapat disimpulkan bahwa kedua data memiliki hubungan yang linier.

Kesimpulan yang didapat bahwa data penilitian ini memiliki 2 dari syarat yang memenuhi terjadinya perhitungan regresi. Maka dapat dinyatakan bahwa perhitungan dapat dilanjutkan.

Tabel 4

Uji Homogenitas Kelas Eksperimen

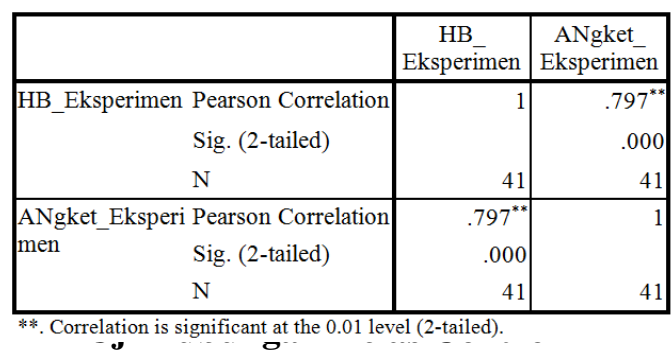

Tabel 5

Uji Homogenitas Kelas Control

\begin{tabular}{|ll|r|r|}
\hline & \multicolumn{1}{c|}{$\begin{array}{c}\text { HB_- } \\
\text { Kontrol }\end{array}$} & $\begin{array}{c}\text { Angket } \\
\text { Kontrol }\end{array}$ \\
\hline HB_Kontrol Pearson Correlation & 1 & $.524^{* *}$ \\
& Sig. (2-tailed) & & .000 \\
& $\mathrm{~N}$ & 41 & 41 \\
\hline Angket_ & Pearson Correlation & $.524^{* *}$ & 1 \\
Kontrol & Sig. (2-tailed) & .000 & \\
& $\mathrm{~N}$ & 41 & 41 \\
\hline & **. Correlation is significant at the 0.01 level (2-tailed).
\end{tabular}

\section{HASIL UJI PENGARUH/ \\ LINIEARITAS}

Pada tabel 6 dan 7 hasil uji pengaruh/linearitas untuk kelas eksperimen dan kelas control diketahui sig. berskor 0,00 yang berarti lebih kecil dari 0,05 . Hal ini menunjukkan bahwa ada pengaruh antara model eksperimen dengan eksplorasi dan ada pengaruh antara model control dengan eksplorasi.

Tabel 6

Uji Pengaruh/Linearitas Kelas Eksperimen

\begin{tabular}{|ll|r|r|}
\hline & & $\begin{array}{c}\text { HB_- } \\
\text { Kontrol }\end{array}$ & $\begin{array}{c}\text { Angket_ } \\
\text { Kontrol }\end{array}$ \\
\hline HB_Kontrol & Pearson Correlation & 1 & $.524^{* *}$ \\
& Sig. (2-tailed) & & .000 \\
& $\mathrm{~N}$ & 41 & 41 \\
\hline Angket_ & Pearson Correlation & $.524^{* *}$ & 1 \\
Kontrol & Sig. (2-tailed) & .000 & \\
& $\mathrm{~N}$ & 41 & 41 \\
\hline
\end{tabular}

Tabel 7

Uji Pengaruh/Linearitas Kelas Control

\begin{tabular}{|c|c|c|c|c|c|}
\hline \multirow[b]{2}{*}{ Model } & \multicolumn{2}{|c|}{$\begin{array}{l}\text { Unstandardized } \\
\text { Coefficients }\end{array}$} & \multirow{2}{*}{\begin{tabular}{|c|}
$\begin{array}{c}\text { Standardized } \\
\text { Coefficients }\end{array}$ \\
Beta
\end{tabular}} & \multirow[b]{2}{*}{$\mathrm{t}$} & \multirow[b]{2}{*}{ Sig. } \\
\hline & B & Std. Error & & & \\
\hline 1 (Constant) & 11.884 & 14.220 & & .836 & .408 \\
\hline HB_Kontrol & .715 & .186 & .524 & 3.840 & .000 \\
\hline
\end{tabular}

Mengetahui besarnya pengaruh model terhadap eksplorasi pada tabel 8 menunjukkan besarnya model eksperimen mempengaruhi eksplorasi yaitu sebesar $63,6 \%$. Sedangkan pada tabel 9 besarnya model control mempengaruhi eksplorasi sebesar 27,4 $\%$.

\section{Tabel 8}

Model Summary ${ }^{\mathrm{b}}$

\begin{tabular}{|c|c|c|c|c|}
\hline Model & $\mathrm{R}$ & $\begin{array}{c}\mathrm{R} \\
\text { Square }\end{array}$ & $\begin{array}{c}\text { Adjusted R } \\
\text { Square }\end{array}$ & $\begin{array}{c}\text { Std. Error of the } \\
\text { Estimate }\end{array}$ \\
\hline 1 & $.797^{\mathrm{a}}$ & .636 & .627 & 3.51349 \\
\hline
\end{tabular}

b. Dependent Variable: ANgket_Eksperimen

Tabel 9

Model Summary ${ }^{\mathrm{b}}$

\begin{tabular}{|c|c|c|c|c|}
\hline Model & $\mathrm{R}$ & R Square & $\begin{array}{c}\text { Adjusted R } \\
\text { Square }\end{array}$ & $\begin{array}{c}\text { Std. Error of } \\
\text { the Estimate }\end{array}$ \\
\hline 1 & $.524^{\mathrm{a}}$ & .274 & .256 & 9.31824 \\
\hline
\end{tabular}

a. Predictors: (Constant), HB_Kontrol

b. Dependent Variable: Angket_Kontrol 
Berdasarkan hasil diatas, dapat dinyatakan bahwa model eksperimen dan control sama-sama memiliki pengaruh terhadap ekplorasi mahasiswa. Hanya saja model eksperimen memiliki pengaruh yang lebih besar $(63,6 \%)$ daripada model control $(27,4 \%)$. Hal ini juga dapat terlihat pada rata rata hasil belajar dimana mahasiswa di kelas eksperimen memiliki rata-rata lebih besar $(80,88)$ daripada kelas control $(75,98)$. Dan hasil angket eksplorasi mahasiswa di kelas eksperimen juga lebih tinggi $(90,32)$ daripada kelas control $(66,20)$.

Berdasarkan hasil penelitian ini, model pembelajaran Student Facilitator and Explaining dapat dinyatakan sebagai salah satu model pembelajaran yang dapat mengaktifkan siswa dalam proses pembelajaran, siswa merasa senang dalam mengikuti kegiatan pembelajaran, dikarenakan dalam model ini siswa diberikan kesempatan untuk mengungkapkan ide-idenya pada temanteman sekelompoknya sehingga menimbulkan rasa percaya diri pada siswa untuk menyampaikan ide-ide kepada teman-temannya.

Hasil penelitian ini didukung oleh penelitian yang dilakukan oleh Andari (2013), bahwa penerapan model Student Facilitator and Explaining (SFAE) pada materi energi dan usaha di SMP Nurul Islam dapat meningkatkan hasil belajar siswa, baik ranah kognitif, ranah afektif dan ranah psikomotorik.

Penelitian lainnya yang mendukung penelitian ini adalah penelitian yang dilakukan oleh Andriyani (2017) bahwa ada pengaruh model pembelajaran Student Facilitator and Explaining terhadap motivasi belajar sejarah kebudayaan Islam siswa kelas IV MIN 2 Bandar Lampung secara signifikan.

Prasetyo (2010) mengemukakan kelebihan model pembelajaran Student Facilitator and Explaining yaitu : (a) Dapat mendorong tumbuh dan berkembangnya potensi berpikir kritis siswa secara optimal; (b) Melatif siswa aktif, kreatif dan menghadapi setiap permasalahan; (c) Mendorong tumbuhnya tenggang rasa, mau mendengarkan dan menghargai pendapat orang lain; (d) Mendorong tumbuhnya sikap demonstrasi; (e) Melatih siswa untuk meningkatkan kemampuan saling bertukar pendapat secara obyektif, rasional guna menemukan suatu kebenaran; (f) Mendorong tumbuhnya keberanian mengutarakan pendapat siswa secara terbuka; (g) Melatih siswa untuk selalu dapat mandiri dalam menghadapi setiap masalah; (h) Melatih kepemimpinan siswa; (i) Memperluas wawasan siswa melalui kegiatan saling bertukar informasi, pendapat dan pengalaman antar siswa.

Pembelajaran pada kelas kontrol menggunakan metode konvensional. Guru menjadi pusat pembelajaran, siswa hanya memperhatikan, mencatat penjelasan guru, dan mengerjakan soal yang diberikan. Hanya siswa-siswa berkemampuan lebih yang berani dan antusias bertanya dan menjawab pertanyaan yang diberikan guru. Siswa lain hanya diam menunggu jawaban dari temannya. Hal ini terlihat bahwa kurang terjalinnya interaksi siswa dengan siswa maupun siswa dengan guru. Dari pengerjaan latihan soal terlihat masih ada beberapa siswa yang belum terbiasa mampu menggali dan menggunakan informasi yang diperoleh untuk menyelesaikan masalah dalam soal tersebut secara matematis.

\section{KESIMPULAN DAN SARAN}

\section{KESIMPULAN}

Berdasarkan hasil penelitian dan pembahasan dapat disimpulkan bahwa penerapan model Student Facilitator and Explaining (SFAE) pada materi Penegakan Hukum di Indonesia pada Program Studi Pendidikan Guru Sekolah Dasar FKIP UMSU tahun ajaran 20182019 mempengaruhi kemampuan eksplorasi mahasiswa, baik ranah kognitif, ranah afektif dan ranah psikomotorik. Model eksperimen memiliki pengaruh yang lebih besar 
$(63,6 \%)$ daripada model control $(27,4 \%)$. Rata rata hasil belajar dimana mahasiswa di kelas eksperimen memiliki rata-rata lebih besar $(80,88)$ daripada kelas control $(75,98)$. hasil angket eksplorasi mahasiswa di kelas eksperimen juga lebih tinggi $(90,32)$ daripada kelas control $(66,20)$

\section{SARAN}

1. Dosen/Guru hendaknya memberi motivasi atau penghargaan berupa nilai terhadap tugas kepada mahasiswa/siswa, sehingga mahasiswa/siswa lebih termotivasi untuk belajar karena merasa dihargai.

2. Model pembelajaran Student Facilitator and Explaining (SFAE) dapat dijadikan model pembelajaran alternatif untuk memvariasikan model pembelajaran.

3. Untuk peneliti lain, dapat meneliti aspek hasil belajar afektif dan psikomotorik yang lainnya.

\section{DAFTAR PUSTAKA}

Abram Rinekso Langgeng (2012) Pengaruh Penerapan Metode Pembelajaran Student Facilitator And Explaining Terhadap Minat Belajar Siswa Pada Matapelajaran Tik Di Sma N 1 Mertoyudan Tahun Ajaran 2011/2012. D3 thesis, UNY.

Andari, Wuri Dita. 2016. Penerapan Model Pembelajaran Student Facilitator and Explaning (SFAE) untuk Meningkatkan Hasil Belajar Fisika Kelas VIII SMP Nurul Islam, Skripsi, 2017, Universitas Negeri Semarang, Semarang.

Andriyani, Yunita. 2017. Pengaruh Model Pembelajaran Cooperative Tipe Student
Facilitator and Explaining Tehadap Motivasi Belajar Sejarah Kebudayaan Islam Kelas IV MIN 2 bandar Lampung, Skripsi, Universitas Islam Negeri Raden Intan, Lampung.

Huda Miftahul. 2013. Model-model Pengajaran dan Pembelajran. Yogyakarta: Pustaka Pejara

Istarani. 2011. Metode Pembelajaran Inovatif. Medan: Media Persada.

Pontoh, Sahril Mohamad (2019, 22 April), Kelebihan Dan Kekurangan Sistem Hukum Indonesia. Tulisan pada http://sistemhukum.blogspot.com/2014/12/k elebihan-dan-kekurangansistem-hukum.html.

Prastyo. E. 2010. Pengaruh Model Studen Faciitator and Explaining terhadap aktivitas dan hasil belajar siswa materi invertebrate di SMA 1 Boja.Diakses dari http://lib.unnes.ac.id/3857/1/662 7.pdf. Diakses pada hari kamis 21 Juli 2016

Ruseffendi, E. T. 2005. Dasar-dasar Matematika Modern dan Komputer untuk Guru Edisi 5. Bandung: Tarsito.

Sugiyono, 2013.Metode Penelitian Kuantitatif Kuantitatif Dan $R$ \& $D$. Bandung: Alfabeta 